Portland State University

PDXScholar

8-10-1972

\title{
The Relationship of Written Expression to Self Concept in Primary Children
}

Anna Lou Case

Portland State University

Follow this and additional works at: https://pdxscholar.library.pdx.edu/open_access_etds

Part of the Curriculum and Instruction Commons, and the Educational Psychology Commons Let us know how access to this document benefits you.

Recommended Citation

Case, Anna Lou, "The Relationship of Written Expression to Self Concept in Primary Children" (1972). Dissertations and Theses. Paper 1562.

https://doi.org/10.15760/etd.1562

This Thesis is brought to you for free and open access. It has been accepted for inclusion in Dissertations and Theses by an authorized administrator of PDXScholar. Please contact us if we can make this document more accessible: pdxscholar@pdx.edu. 
AN ABSTRACT OF THE THESIS OF Anna Lou Case for the llaster of Science in Elementary Education presented August I, 1972.

Title: The Relationship of Written Expression to Self Concept in Frimary Children.

APPROVBD BY NDIBCRS OF THE THESIS COMIITTE:

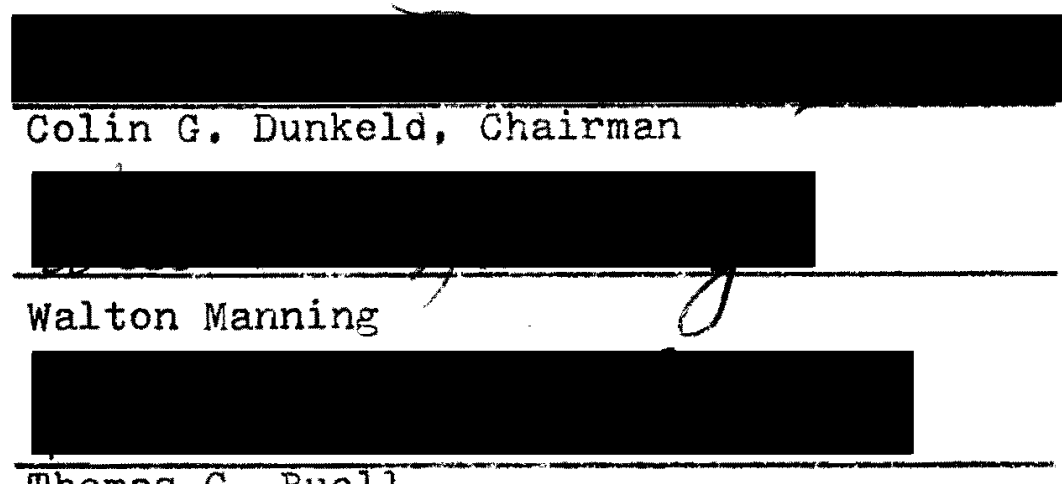

Thomas C. Buell

This thesis, the outcome of nearly three years of preparation, including study, development of procedures, trial and observation, was begun in an attempt to answer the following questions: How may original writing among elementary pupils be motivated successfully? Can positive feelings about self be pronoted to a measurable degree as a result of emphasizing Individual oral and written expression?

Although much thinking and evaluating occurred during the three years, the experinentation and results reported here are limited to the work accomplished and findings obtained during the third year. The twenty-six chidoren 
involved in this study were third-year elementary pupils, whose ages ranged from seven to nine years. During the experimental period, listening, speaking, thinking, and writing were emphasized in the language arts program. A variety of topics provided subjects for written composition.

To test the hypothesis that a measurable increase in self concept or self report ratings could be brought about by experiencing feelings of success and acceptance as a result of self-expression in writing, the Plers-Harris Children's Self Concept Scale was administered to two third grade classes, the experimental group and a control group, at the beginning and at the conclusion of an eight-week experimental period. Average reading scores from the Nietropolitan Achievement Test, Form $F$, were available as an index to the ability of the two groups.

During the experimental time, a writing topic was presented to the experimental group daily. Questions were used to promote discussion, elicit ideas, and encourage thinking and interest. When the majority of the group members had participated orally, and appeared to be interested and involved, paper was distributed and writing was begur. The writer could choose the form his writing was to take, and a variety of ideas could be derived from the topic presented. The result might be an account of a personal experience, orlginal imaginative writing, rhymed or unrhymed verse, or a factual report.

At the conclusion of the eight-week experimental period, 
self report scores of the two groups were compared. To demonotrate a significant change in score from the initial to the final report, a difference in individual raw scores of ten or more points was required. The raw scores of four subjects in the experimental group, and two subjects in the control group increased by ten or more points. However, the findings ofthis study indicated no significant differences to the self concepts of children in the experimental group as compared to the self concepts of children in the control group as a result of the writing treatment. 
THE RELATIONSHIP OF WRIPTEN EXPRESSION

TO SELF CONCEPT IN PRIIARY CHIIDREN

\title{
by
}

ANNA IOU CASE

A thesis submitted in partial fulfillment of the requirements for the degree of

\author{
MASTER OF SCIENCE \\ in \\ ELEMENTART EDUCATION
}

Portland State University

1972 
TO THE OPFICE OF GRADUATE STUDIES:

The members of the Committee approve the thesis of Anna Iou Case presented August 10, 1972.

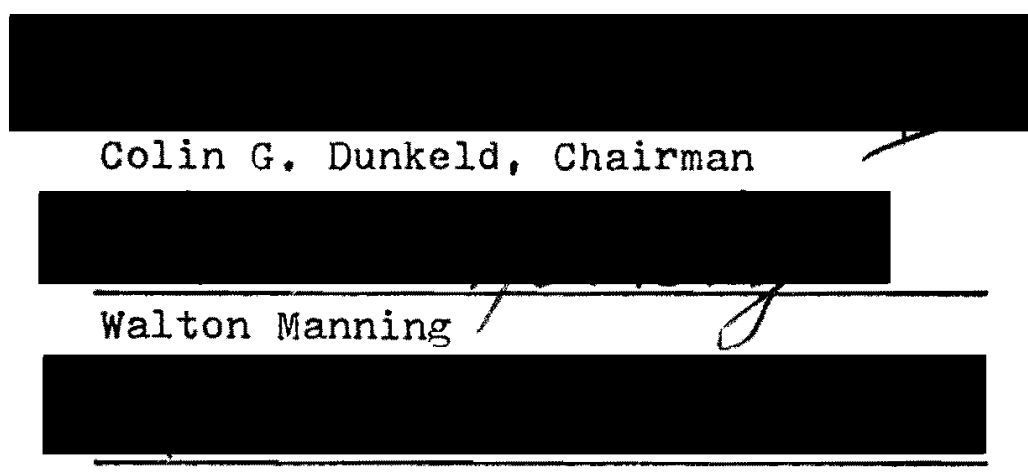

Thomas C. Buell

APPROVED:

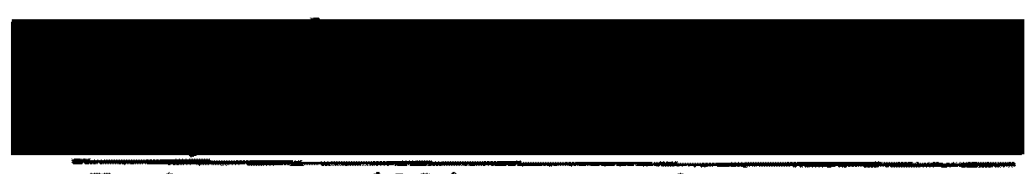

Forbes H. Williams, Chairman, Department

of cunniculum and. Inctruation

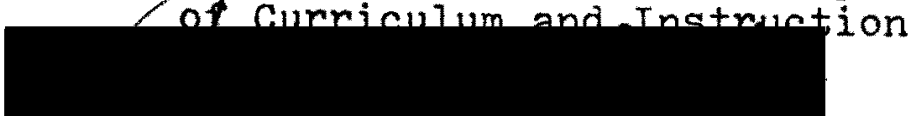

David T. Clark, Dean of Graduate Studies

August 10, 1972 


\section{ACKNOWLEDGMENTS}

I wish to express my appreciation to my thesis advisor, Dr. Colin Dunkeld, for his encouragement and many valuable suggestions.

Also, I am deeply grateful to the excellent instructors at Portland State University in whose classes it has been my privilege to pursue my graduate studies. 
TABLE OF CONTENTS

PAGE

ACKNOWLEDGMENTS . . . . . . . . • • • . • •

LIST OF TABIES . . . . . . . . . . . . . . .

CHAPTER

I INTRODUCTION . . . . . . . . . . 1

II REVIEW OF THE IITERATURE . . . . . . . 4

Self Theory ......... 4

Writing Theory . . . . . . . 13

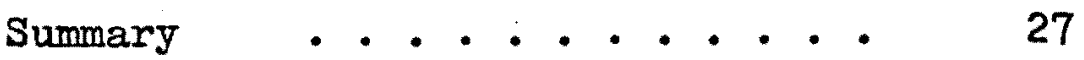

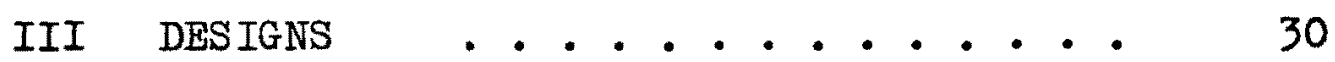

The Original Writing . . . . . 31

Selection of Subjects. . . . . 35

Selection of Rating Scale. . . 37

Testing and Methods ..... 40

Treatment ......... . . 41

IV ANALYSIS OF DATA . . . . . . . . 44

Results . . . . . . . . 44

Findings . . . . . . . . . 49

Subject Case Studies . . . . 50

V INTERPRETATIONS AND IMPLICATIONS . . 58

Summary . . . . . . . . 61

REFERENCES . . . . . . . . . . . . . 63

APPENDIX 


\section{IIST OF PABLES}

$\begin{array}{ll}\text { TABLE PAGE } & \text { PA }\end{array}$

I Self Concept Report Scores . . . . . 46

II Comparison Made . . . . . . . . 47

II Comparisons of Experimental and Control

Groups . . . . . . . . . 48 


\section{CHAPTER I}

\section{INTRODUCTION}

Self theory suggests an awareness of the individual self as distinct and different from all others. The self concept, or idea of self, is derived from the individual's perception of his being in relation to the environment. Feelings about self are developed through interaction with parents, other family members, peers, school companions, and adult acquaintances. Awareness of physical attributes may contribute to the individual's feelings about self. Personality and social concepts are related to self-image since these, also, result from interpersonal relations. Having good feelings about self, or self-esteem, appears to be important to the individual's social, emotional, and academic development. The self concept can be modified by the school environment; therefore, it is becoming increasingly apparent that educators must concern themselves with the task of furthering each individual's feelings of dignity and worth in order that he may develop his potential or ideal self. Early sohool experiences must be arranged not only to interest, challenge, and motivate the individval, but to assure success and to promote feelings of self worth.

It is believed that interpersonal relationships are fostered by means of language use. Therefore, experiences 
which promote the development of listening, thinking, speakIng, writing, and reading contribute to increased understanding of self and others. Oral language, the basis of all verjal learning, is acquired by listening and imitating. Although thinking is possible in the absence of language, thought and cognition are related to and may be facilitated by language. Written language is a symbolic representation of sound, and has been described as an extension of oral language or speech. Reading restores inner or oral language to the written symbols. The language arts, therefore, are viewed as being interrelated. Through language use, the desire for learning and a need for reading will occur according to each individual's pattern of development.

$$
\text { stalento Prosum }
$$

Orie purpose of this study was to devise and experiment with techniques designed to promote individual writing or composition among children, and to evaluate the usefulness or productiveness of those techniques. A second purpose was to test the hypothesis that positive feelings about self can be increased measurably among children as a result of emphasizing composition or original writing in the curriculum. It was believed that experiences designed to promote oral language would provide a basis for written expression and reading as wel and that, through thinking, speaking, and listening, children may be led to discover that they have had experiences which are of interest to themselves and others, and which can be comunicated to others orally and in writing. What is written can become a permanent record of the 
individual's recalled experiences, fmaginative ideas, or thoughts. It can be read by others. Acceptance of the writing by others implies acceptance of the writer. The teacher's encouraging and appreciative comments may free the imagination for further writing. In addition, the writer's satisfaction with his composition appears to be a motivating factor in future endeavors.

Writing can provide a basis for reappraisal of the self-image. If the writing is accepted and appreciated, positive feelings about self may be increased. As the writer receives recognition and encouragement, his feelings of anxlety may be lessened. The teacher's careful listening as the author reads his composition helps satisfy a need for attention and builds self-esteem. 


\section{CHAPTER II}

\section{REVIEW OF RELATED IITERATURE}

Numerous studies have been reported in the areas of knowledge with which this study is concerned: self theory, and original writing. Usually each area is examined separately. In a limited number of studies, a relationship between the two areas has been considered.

\section{SELF THECRY}

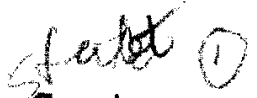

contemporary research increasingly indicates that there is a positive relationship between an individual's self-esteem and the probability that he will achieve academic success. Self theory proposes that the "self" is the integration within an individual of his total perceptions and experiences as known to himself. Initially the child's self-image is formed within the family and home. Earliest impressions in life are thought to be responsible for shaping the system of beliefs or self-appraisals which the individual believes to be true. Certain beliefs about self are held to be fairly constant, while secondary or lesser beliefs are transitory and subject to change. Studies indicate that the child's first idea of himself is a reflection of the parent's idea of him, and that it is not only significantly related to the adjustment of the child, but it will 
influence his personality, behavior, and self concept throughout his entire life (Bledsoe and Garrison 1962).

Origins of Self Theory

The concept of self was introduced into American psychology in 1890, as an entity having as many forms as contexts in which it might be found: a social self, a material self, and a spiritual self. Psychologists since 1890 have explained a wide variety of phenomena related to awareness of self in ways that permit further knowledge to be acquired and new hypotheses to be formulated (Levy 1970).

The term "self concept" has come to apply to the self as the individual perceives or knows himself. Freud used the term "ego" to describe what Adler referred to as "life style." Jung referred to the individual's motives and images as a "collective unconscious." In subsequent writings, the term "self-realization" is used (Gale 1969). Jersild has said of the self:

It is a composite of a person's thoughts and feelings, strivings and hopes, fears and fantasies, his views of what he is, what he has been, what he might become, and his attitudes pertaining to his worth.

Presently the term self concept is used to denote the individual's perceived self and to include the innumerable beliefs, values, and attitudes derived from interaction with others. From studies of contemporary psychologists comes the theory that the maintenance and protection of the perceived self is the basic factor in motivating all behavior. Identified as the phenomenal self by Snygg and Combs 
(1949), the self is defined as an abstraction rather than an entity, encofpassing "a, 1 those parts of the phenomenal field which the individual experiences as part or characteristic of himself." By the phenomenal field is meant the universe, including himself, as it appears to the individual at the moment. They further state:

From birth to death the defense of the phenomenal self is the most pressing, most crucial, if not the only task of existence. Moreover, since human beings are conscious of the future, . . they strive to preserve not only the self as it exists but to build it up and strengthen it against the future of which they are aware.

When each act is seen as an attempt to preserve or to fortify the individual's concept of himself, behavior becomes meaningful.

The self concept is limited to those parts of the phenomenal self which are pore permanent aspects of self; that is, characteristics held to be fairly stable in an individual's self-image. Much importance is placed upon parent-child interaction in the development of the self concept. This is due to certain ideas which have emerged in relation to theories of self: (I) The self concept is learned and includes an individual's perceptions, cognitions, and values. (2) The basis of the self concept is interaction with others, and observation of the reactions of others to the individual.

Parents are present earliest and most consistently; therefore, they are in a position to reinforce or diminish emerging selfesteem (Wylie 1961).

Rainy (1971) points out that a person's awareness of himself may have little relation to reality, since the self 
concept denotes a conceptual rather than an actual self. He suggests that the self is a learned perceptual system which not only influences behavior but is itself altered by behavior and unsatisfied needs. Cnd.

Modification of the Perceived Self

It appears that the self is learned, and arises from experience with people. It is a developmental process, continuing throughout the life of the individual. As he perceives and interprets his environment, his feelings about self become more or less positive and his behavior is altered according to his self-perceptions.

The perceived self is slow to change. However, it is believed that certain conditions may be conducive to change; for example, the possibility of achieving success or attaining increased self-esteem. An individual's perceptions of his environment will result either in growth, and enhancement of self, or in defense, and protection of self (Kelly 1962). Jersild (1998) emphasizes self-understanding as a means to self-acceptance. Through self-acceptance and recognition of significant factors involved, the individual is able to accept criticism without anger or anxiety. Self-understanding makes possible the understanding of others. However, the search for self-understanding is seen as a never-ending process.

If a child's self concept is subject to modification, particularly as affected by responses and expectations of others for him, careful manipulation of the environment may make 
possible greater achievement in a given area (Brookover, Paterson, and Thomas 1962). Acceptance of the child and his efforts by persons important to him may encourage positive feelings of worth. Positive feelings are to be encouraged since the child's thinking, his social behavior, and his personality are directly affected by his perceptions of self.

Self Concept and School Achievement

Previously formed attitudes about his abilities will strongly influence the child's academic performance when he enters school. Much evidence supports the theory that there is a significant relationship between the self concept and school achievement. The self-image can be modified by the school situation as the individual finds success or a lack of success. Perceived attitudes of teacher and peers provide another basis for appraisal of self.

In studies of elementary school children, Bledsoe and Garrison (1962) found correlations between achievement and self ideal concept consistently positive and significant with few exceptions. A study by Brookover, Paterson, and Thomas (1962) also indicates that the individual's concept of his ability is positively related to achievement. They isolated specific self concepts of ability related to various academic areas, and found that these differed not only according to area, but from the self concept of general ability as well. A study made to determine the distinguishing characteristics of children from impoverished backgrounds who achieve 
success in elementary school learning indicated that a positive self-image was most highly related to achievement status. It was proposed that children reach school having varying appraisals of self formed in early childhood, and that the teacher's response to each child may vary according to the child's reflected experiences. The child's feelings of selfworth are enhanced or lessened in turn, as he perceives the teacher's response to his developing self (Davidson and Greenberg 1967).

A program of child study in which educators organized into groups in order to gain insight into children's behavior and development has been described by Brandt and Perkins (1956). Important changes within the classroom were reported. Teachers became more acceptant of the children; they used increased praise and encouragement; they displayed greater sensitivity to the principles of human development; and they more fully recognized the uniqueness of each individual. Children exhibited more positive and less negative behavior. However, no change in academic achievement was noted.

An investigation of children's perceptions was made by Combs and Soper (1963): Prom observations of children's behavior inferences and predictions were made concerning the individual's future behavior. It was proposed that the behavior of the individual indicates his perception of himself and the world at a given time and provides an appropriate basis for study of the individual's self-image. The study involved a group of children who advanced through kindergarten and first 
grade. A number of conclusions were reached: (1) Of greatest importance to the child is the feeling of personal adequacy in his perceptual world. (2) Teacher judgments about children's behavior are affected by personal values. (3) A positive correlation was found between children's perceptions and their behavior as described by their teachers. (4) Children seemed to experience a decrease in feelings of adequacy as they moved from kindergarten to first grade.

Bledsoe and Garrison (1962) have stated that those concerned with the educative process must take a positive view of each child as an individual. The educator must recognize each student as a person whose talents and abilities must be apprem ciated and encouraged. Levy (1960) suggegts that an accepting, understanding climate can promote positive feelings of self. Davidson and Greenberg (1967) warn that early establishment of homogeneous classes tends to reinforce the feeling among many children that they are less than adequate. Leuba (1962) emphasizes that it is important for each individual to feel he is understood and unconditionally accepted as he is. He suggests that through empathy and sensitivity to other's feelings, it is possible to perceive from another's point of view and to understand his concerns, feelings, and ambitions.

\section{Measurement of the Self Concept}

The self concept has been defined as the "self known to the self." It has been stated that the self concept is what an individual believes about hinself, while the self report, frequently used to measure self concept, reveals instead what 
the individual says about himself. Reasons for making this distinction have been advanced by Combs and Soper (1963):

(1) The subject may not perceive his self with absolute clarity. (2) Words are inadequate symbols with which to express feelings. (3) True feelings about self may be concealed. (4) Feelings of inadequacy may prevent an accurate description from being given. (5) Being asked to report feelings and behavior immediately changes the subject's perceptions. Similar beliefs have been expressed by other writers. Travers (1955) contends that the use of the self inventory approach is not reliable at the lower age levels, as he beIieves the child unready to attach language symbols to his emotional states. For most personality inventories the individual must be accurate in his self appraisals and honest in his responses if valid information is to be received. It has been suggested that tests for measuring personality characteristics may result in harm to the child when improperly used by unskilled persons. When results have been obtained, the interpretation may be more difficult than the testing procedure itself (Lindeman 1967).

Since quantification in measurement lends itself to precision and objectivity, tests which produce numerical scores are frequently selected as evaluation devices. It should be remembered, however, that quantification of human characteristics should be interpreted with reservation. Ferguson (1966) states:

Scores on attitude tests, personality tests, and the like, are in effect ordinal variables; that is, 
rank ordering is permitted, although statements about the equality of differences among members are not possible. However, for statistical purposes, they are treated as if they were interval or ratio variables.

Studies related to an individual's self perception are therefore not easily made. Since reports of beliefs about the individual self must be made by the individual, and many persons are reluctant to express honestly and openly feelings about self, results of the self report must be appraised with restraint. However, in spite of these limitations, self reports do reveal useful information and provide insight into the child's perception of himself and his environment.

In an attempt to study concepts and attitudes about self more directly, Jersild (1952) obtained and analyzed 2,893 compositions on each of two subjects: "What I Iike About Myself" and "what I Dislike About Nyself." The compositions were written by students from the fourth grade level through college. Although a number of younger children were Interviewed, it was believed that children below the fourth grade would experience too much difficulty in writing their answers. Items mentioned in the compositions included physical characteristics, health, material possessions, home and family, and special talents and abilities. School and school performance were frequently mentioned as being liked or disliked. At nearly all grade levels the writers regarded themselves as lacking ability to succeed in their work at school. Another means by which pupil personality or self concept may be determined is observation. Travers (1955) has stated 
that personality inventories or self reports are to be used for experimental purposes only: "The direct observation of the pupil must remain the primary source of information about pupil development . . " To provide useful information, the observer should be a trained individual and notes or records should be kept. For increased objectivity and reliability, a check list which specifies the traits to be observed is desirable. It must be remembered, however, that any observation is affected by the perceptions of the observer.

\section{WRITING THEORY}

Nany persons have concerned themselves with the study of problems related to written conposition. Studies have shown that relating reading to listening, speaking, and writing effectively reinforces all aspects of the language arts. Evidence indicates that systematic practice of oral and written expression provides for development of greater skill in composition than does writing done on an incidental basis. Ionger and more detailed stories have been obtained from young children who dictated rather than wrote. Investigators have devised a number of ways to study composition. word and error counts have been made. Writing vocabularies have been analyzed. Words most frequently used have been identified. Sentences have been studied to determine their length and complexity. In other studies, self-expression has been emphasized. The individual has been encouraged to write about his own experiences and observations, it being believed that 
greater individuality and increased self-awareness would result.

Beginnings of Original Writing

Dictation of messages and stories by young children has been viewed as an extension of thinking and talking (Cowe 1972). While very young the child associates written or printed material with ideas, and attempts to imitate the act of writing by making marks on paper. Following the experience of dictating, and seeing his words on paper, the child may wish to trace or copy letters. This is seen as the beginning of written expression. Cowe urges "fullness of experience" in order that the child will have something to say and may desire to say it in written form.

The effort which writing requires has been found to have the effect of limiting the extent to which ideas and thoughts are put on paper. Therefore, a pilot program in communication skills was initiated by Smith and Willardson (1971) to allow: children in the first and second grades to record stories on tape at any time they wished. The recorded narratives were typewritten daily. During seven months, over 2,500 compositions were produced by children in four classes. The compositions varied in length from three or four sentences to ten typewritten pages in length. Growth in narrative style (introducing a.topic, developing the main idea, and providing a closing) was observed. Also, as children read their own or other's stories, it was noticed that they made appropriate 
corrections or changes in form. The investigators stated the belief that story sharing will result in improved understanding of others, and increased ability to interpret life experiences.

Words which have significant connotations and meanings will provide the initial vocabulary for the beginning writer. (Ashton-Warner 1964). If writing frecedes reading, it may be that reading will occur gradually and naturally as a result of seeing on paper particular words which have special meaning for the individual.

Enrichment of the child's experience with literature is said to be an important factor in fostering writing (Holbrook 1967). Enjoyment of books and good literature is believed essential to the writing of good English (Clegg 1967); therefore, children must be read to extensively.

Research in Children's Writing

Golub (1971) proposes that writing is the expression of the "inner voice of man." If ideas are precisely stated, a "creative response" is evoked in the listener or reader. Thus he presumes it is the teacher's task to stimulate within the child the awareness of an inner self capable of responding uniquely to all experience. He sees the children's writing as an expression of thinking in a "most intimate voice." Having analyzed samples of children's writing for linguistic and rhetorical growth patterns, Golub confirms what others have observed: greater variety of expression, more imaginative 
writing, more complex sentence patterns, and increased length of compositions as children progress from grades one through six.

To discover the requirements of a favorable writing environment, Kuse and Allar (1971) studied suggestions from teachers, the literature, and the children themselves. Children's suggestions which were followed included having the teacher help with words by writing them either on paper or on the chalkboard, and having a choice of working with a partner or working alone. The children were from two levels in a nongraded program, and two classrooms were available. A short questionnaire was used to learn the children's reasons for their choice of writing arrangements. Analysis of the children's responses showed that those who preferred having the teacher write words on paper at their desks generally liked a quiet atmosphere with no interruption of thought by others. Children who preferred having the teacher write words on the board said they enjoyed sharing ideas and using words and phrases asked for by other children. Those who chose to work with a partner enjoyed the social aspect, and helped each other with writing and spelling. The reason given most often for choosing to worix by oneself was the quiet environment. It was observed that children more often chose to work with a partner when writing plays than when writing descriptions or stories. The study appeared to confirm that class writing experiences can be made more productive by offering a choice of writing environments. 
Another research study compared "global" quality and syntactic maturity in the compositions of second and third grade children (Biesbrock and Veal 1969). Global quality was defined as a broad measure of the child's writing, including level of ability and development. Writing by sixty children who were in the second and third grades was analyzed. Four criteria were: (I) the number of T-units (minimal terminable syntactic units); (2) the mean T-unit length; (3) the number of subordinate clauses; and (4) the number of all clauses. High correlations were found between global quality measures and the number of T-units, the ratio of the clauses to T-units, the number of subordinate clauses, and the number of all clauses. Results indicated that fluency and complexity were related to overall ability or global quality in the writing examined. It was concluded, however, that determination of T-unit length may not provide a reliable basis for distinguishing between levels of quality within a specific age group. Further analysis and comparison of global estimates of quality and syntactic measures of maturity has been suggested by the investigators.

Language is a tool to be used in all phases of learning. Enriching, enlightening experiences must be provided about which children will have purposeful occasion to talk and write (Dawson 1957). Recognizing the dual nature of language (impression and expression), Dawson submits that there is a need for emphasis on communication in guiding language learning. Speaking, which requires use of vocabulary, 
sentence structure, and organization of ideas, is seen as the foundation for written communication. Environmental factors must be arranged for "observing, experiencing, listening, reading, and thinking . . to acquire ideas for speaking and writing."

Reading selected literature, and conducting dialogues prior to writing provided motivation for a fourth grade class (Nesper 1965). In an extended study to determine the effectiveness of the initiating activities, and to develop composition skills, the writing product was regarded as valuable in itself. Questioning promoted exploration of each topic in order that an aspect which could be used for composition might be found. Experiences common to each student provided themes to be developed. Writing was done in essay and poetic form. Increased ability in written expression was attained.

In a study of pre-writing stimuli, Carlson (1960) designed sixteen experimental creative writing lessons which included eight lessons for experimental groups and eight for control groups. Stimuli and green paper were employed to promote writing among the experimental groups. The stimuli included literature, pictures, aural imagery, sensory stimulation and realistic experiences, as well as toys and small objects. As many as 390 children and eighteen teachers were involved in the study, the purpose of which was, in addition to encouraging original writing, to foster original thinking. Three judges were asked to evaluate the compositions according to two scales which she developed, an Analytical Originality 
Scale, and a General Impression Scale. Originality of the composition, versatility of vocabulary, and total number of words used were considered. It was found that the groups of writers who received the various forms of stimuli before writing produced more original writings, using more words and greater variety in vocabulary than did the control groups who received no stimulation and wrote on white paper.

In an attempt to discover procedures by which successful teachers motivated children to write, and to evaluate the effectiveness of their techniques, Smith (1936) used questionnaires, direct observation, interviews, and analysis of samples of writing. The study was particularly concerned with creative writing, which was defined as "any kind of voluntary writing in which the child is free to choose the time of composing, to select the subject matter, and to determine the length and form in which the writing appears." Forms of writing other than creative were termed practical writing, and described as "any writing in which subject matter, length, and form are dictated almost entirely by circumstances or by the teacher." Creative writing, which was said to mirror true individuality, could be either written or dictated. Procedures believed conducive to writing included: (I) Develop a rich background by means of excursions, experiments, and observations. (2) Tell or read stories to children. (3) Encourage honest expression of vital experiences. (4) Free the child; do not tamper or criticize. (5) Provide time for writing. Smith observed that the "effect of writing is more 
important than the product", and concluded that "little has been done by way of discovering the best procedures for encouraging creative writing."

It has been observed that children enjoy illustrating stories, letters, and reports. Drawing is a personal form of expression, as is writing. There seems to be an added incentive for writing when it accompanies illustrations by the writer:

A third grade group that folded paper into parts and planned a sequence of pictures to narrate a story expressed more ideas and, curiously enough, even wrote more words and sentences than they did when they planned and merely wrote. Although this study involved a small group, its carefully evaluated findings support the observations of many primary teachers. Apparently the expression of ideas in a visual medium helps many children to cross the threshold from oral communication to graphic symbols to written symbols (Burrows 1966).

Specific techniques and topics used to stimulate and encourage writing were intended to motivate, to provide access to areas of life experiences, and to develop fluency in written expression (Certner 1964). Oral preliminaries were provided that allowed complete individuality. Topics were presented and, through discussion, the possibilities for writing were expanded. Alternate choices for writing could be made. Draper (1969) confirms that occasions for writing must be provided, not only to encourage students to become self-sufficient writers, but to clarify and illuminate their lives and to communicate their perceptions to others. Draper stresses the importance of respect and trust in the relationship of teacher and students: "To write honestly for 
him, a student must trust his teacher. The teacher can promote trust by behaving not as a judge. . . but doing what he can to help his student grow through his writing." He also mentions that teachers should be aware that the process of writing is related to the growth of students; and that this awareness could help teachers become more patient with their students and feel "less personally liable for their products."

In a study of language teaching, LaBrant (1951) specifies that writing is learned best when there is opportunity for personal expression, for conferences about the writing produced, and for revision of written work. Writing is seen as a means to personal, creative expression:

Just as with speech there is the intimate, personto-person talk, so with writing there is the account of experience--reactions to what is seen, felt, feared, touched... Here are narratives of the simple events of the home, accounts of increasing understanding about life, expression of concern as to the future of the world.

IaBrant concludes that for reasons of mental health and emotional release, the opportunity for written expression deserves an important place in the school program. That selfexpression has therapeutic value is also mentioned by Carrithers (1964) who believes that freedom to say, write, or dictate as the individual wishes promotes feelings of selfrespect. Language is seen as a means to the expression of self. Creative writing follows experiences with speaking and listening, and is begun through dictation. Written 
communication, following the experience of dictating, is seen as "talk written down."

Cole (1966) used individual writing as a form of catharsis for her students, to bring about spiritual renewal or to eliminate repressed desires or memories that produced an undesirable effect upon the personality. Opportunity was provided for writing freely about such topics as "Home Iife" and "Our Secret Crimes." Contents of the compositions were not revealed if that was the writer's wish. Students wrote to overcome fears, to forget, and finally, to rebuild self-image. The need for encouragement, acceptance, and rapport between teacher and class was emphasized.

\section{The Writing of Poetry}

Most studies of the use of poetry and poetry writing with children have been descriptive or anecdotal due to the difficulty, well-recognized among investigators, of adapting experimental research methods to the study. However, a number of reports of the use of poetry writing in the classroom are available.

Literature related to the writing of poetry generally agrees that (1) a formal prescriptive approach should be avoided, and (2) a free and accepting classroom atmosphere should be maintained. In an attempt to test the hypothesis that there was no difference between "free" and "semistructured" methods in terms of the effect on the poetry writing of fourth grade children, Shapiro and Shapiro (1971) 
developed two experimental programs for poetry writing. Each program consisted of fifteen lessons, avoided a formal approach, and provided six opportunities to write poems over a period of five weeks. The "free" lessons stressed listening to seventy poems by well-known poets. These poems were heterogeneous in terms of content, style, and form. No arrangements were made for group work, but the children were encouraged to share their poems with each other. The "semistructured" lessons consisted of a sequence of carefully planned group and individual activities centered upon the five senses and designed to (I) increase facility with words, develop unusual expression of ideas, and (3) guide children to consider questions concerning the quality of good poetry. Some poetry by children as well as by adults was read aloud. The experimental subjects included eighty-four fourth grade pupils, with forty-two in the "free" and forty-two in the "semi-structured" program. To measure the effect of the lessons on the subjects' ability to write poetry, a special rating scale was developed. Five elements of poetry which both programs had been designed to emphasize were considered: unity, choice of words, rhythm, imagery, and affective quality. Three independent variables, intelligence, language achievement, and creativity, were measured by appropriate tests. Three judges rated the poems which had been transcribed in order that the ratings would not be influenced by the quality of writing and spelling. Results of the experiment indicated that the "semi-structured" lessons were more 
effective than the "free" lessons. On the basis of this experiment, it was suggested that children can be taught to express themselves in poetry, and that there is no single method to encourage individual expression. Other possible effects of poetry lessons recommended for investigation as a result of this study are (I) dimensions of poetry not included on the rating scale; (2) skill in dealing with prose; and (3) more adequate development of self concept.

Pictures about nature provided the stimulus for children in the fifth grade to write Haiku poetry (Shay 1971). This kind of poetry, oriental in origin and concerned with things in nature, was believed to encourage children "to express their feelings or thoughts about the little moments of life." Shackleford (1972) has described Haiku writing as "a creative opportunity." She indicates that it is more often a fragment, evoking a feeling or mood, than it is a sentence; and by being restricted to seventeen syllables, the writer becomes more aware and observant.

Staudacher (1968) reports that reading aloud to children selected poetry, preferably free verse, is an effective way to inspire poetry writing. She believes that children are innate poets because they are sensitive to changes of emotion in themselves and others. She considers it the teacher's challenge "to release the poetry" within the mind of the child. Petty and Bowen (1967) suggest the use of a number of forms of poetry: the couplet, the triplet, limorick, and cinquain. They emphasize, however, that the form 
of a poem is only an aid to expressing content. They suggest that children be "directed away from a preoccupation with making words rhyme" and encouraged to express emotion or imagery.

Chukovsky (1963) suggests that children between the ages of two and five reveal a preference for poetry, and when they discover that words rhyme, they delight in rhyming. Versification is regarded as part of a child's natural linguistic development. By studying the speech of childhood, Chukovsky writes, "It is possible to discover the whimsical and elusive laws of childhood thinking."

To encourage the writing of poetry, much poetry must be heard (Applegate 1954). Things of every day must be seen and valued in a fresh new way. Appreciation is shown for a phrase, idea, or image. Rhyming is not emphasized. Applegate states, "A poet and a child are natural egoists. But public opinion, and the formal school approach, strip them of their honesty and naturalness of expression." Walters (1962) suggests that children grow in ability and perception when they critically evaluate their own poems and select more vivid and specific words. Burrows (1964) places the importance of poetry writing on the satisfactions gained from expressing innermost thoughts: "This is the reason we want children to become acquainted with the power of original expression. . . to find out what they really think and feel." 
Evaluation of Children's Writing

All creative writing should be accepted with appreciative comments, and never marked except for an honest, encouraging word or phrase (Applegate 1961). The opportunity for writing is believed to be of special value to the individual who is otherwise hesitant in committing himself: "Often the more sensitive the child, the less articulate he is and the more he is in need of a medium of expression that is a little more private than talking."

Early attempts to evaluate composition used grades, rating scales, or single essays as criteria. To determine the validity of essay ratings as compared to scores derived from multiple-choice and other tests used in predicting writing ability, an experimental plan was devised by Godshalk, Swineford, and Coffman (1966). Raters were asked to make global judgments of each paper, using three ratings: supe-rior, average, and inferior. On the basis of this study it was found that the rating of twenty-minute essays proved sufficiently reliable as to suggest that rating as a method of evaluation does make a contribution to the measurement of writing skill. Correlation of essay ratings and test scores indicates that skill in writing and the ability to compose answers to essay questions is an important outcome of education.

In addition to composition rating, other methods for studying composition have been devised. Quantification of the writing product has been attempted by counting the 
number of words used, the number of errors made, and determining length and variety of sentences. The number and length of sentences written at various grade levels has provided a basis for comparison. Ioban (1963) reduces measures of writing to the amount of subordination, conventional usage, syntax, grammar, and frequency or diversity of vocabulary.

It must be concluded that the evaluation of written composition presents a difficult problem. Studying sentence length, number of words, number of errors, and variety in sentence structure may be less important than the ideas expressed and the feeling of achievement and success experienced by the writer. Through oral and written expression children may gain in confidence and poise. The individual's writings are communications of an inner "self" which may be enhanced as he sees his writing accepted and appreciated.

\section{SUUMMARY}

Self theory suggests a "self" that is the integration within the individual of his total perceptions and experiences as known to himself. It is derived from early experiences with others: parents, siblings, peers, and more remote adults, such as teachers. The concept of self develops as attitudes of others toward the individual are perceived. It is believed that by the third year the self image is established. Feelings about self may have lasting influence on personality and behavior. Protection of the perceived self is seen as a motivating factor in all behavior. 
The concept of self is believed to affect the individual's academic achievement when he enters school. The successful student is usually one who has more positive selfperceptions and is optimistic about his future performance, whereas underachieving students lack self-reliance, a sense of personal worth, and a feeling of belonging. It is believed that the school environment and appropriate teaching methods can promote positive feelings of self. Provision must be made for enriching experiences about which the individual will have occasion to talk or write. Freedom to say, write, or dictate as he wishes is believed to be conducive to mental health. Through oral and written expression, children may gain in confidence and poise. The composition is not as important as the feeling of achievement and success experienced by the writer. Acceptance and appreciation of the individual's writing may lessen anxiety and enhance selfimage.

Ianguage is seen as having the power to help fulfill desires and needs. Oral language is developed through communication between the child and the people in his environment. Skill in written expression develops from skill in the use of oral language. The child's first opportunity to see his thoughts in written form occurs when his speech is recorded in writing. It is believed that the child's pictorial representation of ideas affords him the security he needs in order to venture from oral to written expression. Specific techniques have been used to stimulate and 
encourage writing. Oral preliminaries allow for thinking and remembering. Complete individuality and originality is possible. Patience, acceptance, and mutual trust of teacher and pupil will promote honest and self-sufficient writing. Writing is seen as a developmental process related to growth.

Although the ferceived self is slow to change, under certain conditions change may occur. Feelings of success can bring about favorable changes. Early school activities should promote success and feelings of worth, dignity, and self-realization. Oral and written expressions are communications of the child's "self", and if the child's writings are accepted and appreciated, his feelings about self may be enhanced. 


\section{CHAPTER III}

\section{DESIGNS}

The purpose of this study was twofold: (1) to devise and experiment with techniques designed to promote individual writing or composition among children in the third grade and to evaluate the usefulness or productiveness of those techniques, and (2) to test the hypothesis that positive feelings about self can be increased measurably among children as a result of emphasizing original writing in the curriculum. To test this hypothesis, self-report scores of an experimental group, pupils in a third-grade class who were encouraged to do individual writing activities every day during an eight-week experimental period, were compared with self report scores of a control group, pupils in a thirdgrade class who followed the standard curriculum. Both groups responded to a self concept inventory at the beginning and at the conclusion of the eight-week experimental period. Results were analyzed to determine whether there were significant differences between the two groups initially, and again at the close of the experimental period. Also compared were the initial scores to the final scores within each group. 


\section{THE ORIGINAL. WRITING}

Most human behavior is associated with some form of language. Self-understanding and interpersonal relationships may be fostered by language use. Therefore, an important educational concern is the promotion of language facility.

Oral language is acquired by listening and imitating. Thinking is related to and may be facilitated by language. Written language, the symbolic representation of sound, is based upon oral language. Ianguage is restored to the written symbols through reading. It appears, then, that the language arts, listening, thinking, speaking, writing, and reading are interrelated aspects of language.

Development of Writing Plan

Original writing in this study was used to encourage learning among children who had experienced difficulty with reading due to immaturity or emotional, psychological, or learning handicaps. It was believed that each child must feel accepted and valued in order to learn. Social, physical, emotional, and intellectual growth occur according to the individual's pattern of development. Learning tasks must be challenging but not discouraging. To attain success is to attempt greater achievement. Direct experiences with tangible objects and actual events, particularly those which appeal to a number of the senses, are likely to be remembered. Abstract or verbal experiences may be less well 
remembered. A basis for oral language use is provided by real experiences. Use of oral language is the foundation for written expression, which involves reading.

The problem was to arrange experiences and to devise techniques which would motivate the related arts of listening, thinking, speaking, writing, and reading. Through the encouragement of original writing, it was hoped that the following goals would be attained: (I) to renew an interest in learning; (2) to improve reading ability through thinking, listening, speaking, writing, and reading; (3) to increase perception and awareness of everyday experiences and things in the environment; and (4) to enhance positive feelings of self through acceptance and appreciation of individual written expression.

It has been observed that many children, even the very young, have a seemingly natural ability to express themselves in a unique and even poetic kind of speech. Novel and original word combinations result in fresh ideas and vivid expressions; for example, a child of three remarked, "Mr. Sun turned his flashlight on", and, "I like the music the wind makes." It is believed that the ability for self-expression can be encouraged through carefully arranged conditions, and that oral expression will provide the basis for written expression. Through speaking and listening, children may be led to discover that they have had significant dramatic experiences which can be expressed in speech or writing. Their original writing can be appreciated by others. To have 
something of value to express on paper reflects favorably upon the writer. Feelings of self-worth are increased. Writing requires a combination of skills: thinking, including, excluding, remembering, and putting words and ideas together in new ways. Writing sharpens perceptual power, increases awareness, promotes understanding, and provides for release of feelings and tensions. Skills of critical reading and thinking may be related to an ability for clarity in written expression.

Principles of Original Writing

Through use and evaluation of individual writing, a number of distinguishing principles have emerged: (1) An experience or idea provides the basis for oral participation and written expression. (2) The writer may choose any aspect of the topic for his composition. (3) Drawing a picture prior to writing is encouraged. (4) The writer is free to choose the form and length of his composition. (5) The writing is unconditionally accepted. (6) The writer is invited to read his composition to the teacher.

It is believed that conditions conducive to freeing written expression can prevail in the school environment. Trust, respect, and acceptance are essential to an atmosphere in which the child is free to write his individual thoughts and ideas. Differences must be encouraged. If the writing does not meet the desired standard, it must be accepted nevertheless. If it is accepted, more writing may follow, and 
the quality may be improved. Mistakes must be overlooked, and encouraging comments made. A feeling of accomplishment and satisfaction in the writing product appears to be a motivating factor in subsequent writing attempts.

Any interesting topic which has significant meaning for the children, or can be related to their previous experiences, may be used as a subject for individual writing. A story may be used to promote writing. Writing may be stimulated by careful observation of something in nature: a seed, a feather, a leaf, or a piece of driftwood. It may follow walks taken for the purpose of listening, discovering textures or designs, or making observations concerning natural history. A reason for writing may be provided by a remembered experience: fun on the farm, a walk in the woods, a trip, or a picnic. Discussion prior to writing is an important part of the language activity. Careful questioning elicits individual contributions, and listener's memories are released. The exchange of ideas appears to be stimulating, even for children who do not participate. Each individual approaches the writing activity in his own way, selecting any aspect of the topic for his composition. Paper is provided in order that it will be available immediately for use in expressing ideas already formed. The paper is six inches in width and twelve inches in length, one-half of it being ruled for writing and the remainder unruled to provide a space for drawing. For some children, drawing an appropriate picture appears to facilitate the initial steps of writing. Other children know 
exactly what it is they want to say, and begin their writing at once. Hesitant writers need individual help and encouragement in order to feel ready to begin. They can be helped to realize that their thoughts and experiences are valuable and should be recorded. If help in spelling is required, words, phrases, and occasionally sentences are written on paper. Children who have unusual difficulty with writing and spelling may dictate their story and copy it under the picture they have made. Each individual is free to choose the form and length he desires for his writing.

As each composition is completed, the writer is invited to read to the teacher. As he reads, he may evaluate the composition, although it is not suggested that he do this. The need for corrections may be observed, and changes made. The teacher's listening indicates acceptance and interest, and may encourage subsequent writing. The child's feelings of success and satisfaction are believed to motivate future writing.

\section{SELECTION OF SUBJECTS}

Two heterogeneous third-grade classes, each composed of twenty-six pupils, constituted the experimental and the control groups. No attempt was made to match the individuals within the groups in any respect. Traditional methods for distributing pupils among five third-grade classes had been followed the previous spring. Room assignments were 
made on the basis of test results and ability as determined by teacher observation. This was done in order that each class would be comparable in ability or performance. The Metropolitan Achievement Test, which had been administered approximately eight weeks earlier, provided the means of determining achievement level. Personality factors were also considered in the placement of pupils, since it was hoped that individuals within each class would be compatible. Also, an attempt was made to have an equal number of boys and girls in each room, and to have the five classes approximately equal in number. The subjects were not grouped in any special way for this study.

Although efforts were made to ensure that the classes would be comparable, various factors impossible to control may have affected the results. It is possible that during the final eight weeks of the school year, certain class members made achievement gains in various subject areas covered by the test, while other individuals made lesser or no gains. In addition, many pupils moved away and left the group to which they had been assigned. New, or incoming pupils were assigned to the class having the smallest number of pupils. It is expected that, due to these factors, there would be variation among the groups. However, the possibility exists that all incoming pupils would have characteristics similar to those of the pupils they replaced. It was on this basis that the two groups were anticipated to be comparable in ability, age, sex, physical attributes, and personality character- 
istics. Metropolitan Achievement Test scores for average reading provided the only means of comparison of ability between the two groups. These scores, available during the final week of the experiment, provided an index of general ability for purposes of analysis. The Metropolitan Achievement Test for Reading is reported to be "one of the best survey tests of reading achievement" for the elementary grades (Buros 1965). Reliability for each subtest is said to be good, and validity obtained through careful study of curricula, judgment of experts, and repeated experiments. Standardization has been done scientifically, and results are reported in ways useful for interpretive purposes. The class means for reading were: the experimental group, 3.46 ; and the control group, 3.40. On the basis of these scores, it is evident that the two groups did not differ widely in general ability.

\section{SELECTION OF RATING SCALE}

A search was made for an appropriate instrument with which to measure individual personality or self-image. The California Test of Personality was obtained, but a number of deficiencies were noted. High scores may represent adjustment or they may indicate knowledge of acceptable behavior and attitudes. For this reason, low scores, representing emotional maladjustment, are considered to be more reliable than high scores. Evidence of validity has been said to be 
lacking almost entirely. The length of the subtests has been described as too short to provide adequate reliability or validity (Travers 1955).

The possibility of adapting the Tennessee Self Concept Scale (Fitts 1965) to meet the abilities of children in the third grade was considered. This test was found reliable when used to measure self-image of the same individuals over an extended period of time. A self-criticism score is derived from the following categories: Identity, Self-Satisfaction, Behavior, Physical Self, Moral-Ethical Self, Family Self, and Social Self. In responding to each item, the subject selects one of five possible responses: Completely false; Mostly false; Partly false and partly true; Mostly true; and Completely true. It is believed that a choice of responses makes possible a more accurate picture of the individual's perceptions of self.

A recently developed test, the Piers-Harris Children's Self Concept Scale entitled, "The Way I Feel About Myself", consists of items which reflect the concerns that children have about themselves. Many items were developed from Jersild's findings concerning the children whose compositions, "What I Like About Myself" and "What I Dislike About Myself", he obtained and analyzed. Jersild grouped his findings into the following categories: (1) Physical Characteristics and Appearance; (2) Clothing and Grooming; (3) Health and Physical Soundness; (4) Home and Family; (5) Enjoyment of Recreation; (6) Ability in Sports, Play; (7) Ability in School, 
Attitudes Toward School; (8) Intellectual Abilities; (9) Special Talents; (10) Just Me, Myself; and (10) Personality, Character, Inner Resources, Emotional Tendencies (Piers 1969). The items, written as simple declarative sentences, were designed to elicit affirmative as well as negative responses. No choice of response has been provided other than "Yes" or "No". The Piers-Harris Scale has a number of advantages for use with pupils in the third grade: It can be administered in group form and requires approximately thirdgrade reading ability. It is quickly completed, requiring about twenty minutes of time. It is appropriate for children of varying abilities. The items are simply worded and easily understood.

The Piers-Harris Scale was developed primarily for research. It is useful to investigators who are concerned with hypotheses related to self theory. It is the opinion of the authors of the test that self attitudes are relatively stable by the age of eight, and therefore, studies confined to a single event or even a week's experience cannot be expected to find significant differences. Changes in group means from one to five points have been found on a retest to be consistently in the direction of a higher score even if no treatment has taken place. An average of standard deviations over several samples at different grade levels indicates that, to obtain a significant difference, a change in individual score of ten or more points is required. Limiting the subject to a response of "Yes" or "No" may force him to make a choice 
that is not altogether accurate. The possibility exists that certain subjects may be inclined toward agreeing (answering "Yes" regardless of the content of the items) or toward disagreeing (answering "No" regardless of item content. With young children, responses may incline toward social desirability as the individual chooses to present a favorable image of himself. Thus the very high scores may not be as accurate as the very low scores (Piers 1969). The scale was judged to have good internal consistency and adequate temporal stability. Factor analysis indicated that an emphasis be placed upon two of the original categories: "Just Me, Myself" and "Personality, Character, Inner Resources, Emotional Tendencies." These subjects were believed to provide a more accurate reflection of the child's general self concept. Raw scores may be compared to percentile rankings and stanine scores, or the following interpretation may be made: Average scores are considered to be those between the thirty-first and seventieth percentiles or between raw scores of forty-six and sixty (Piers 1969).

\section{TESTING AND METHODS}

The experiment was conducted over an eight-week period. The Piers-Harris Chizdren's self concept Scale was use por obtain self concept report scores initially and again at the conclusion of the study. The test was administered to each class separately in its own classroom by its own teacher. 
In both classrooms, however, the testing was done on the same day and at the same time at the beginning, and again at the conclusion, of the experimental period. Similar instructions were given to each group:

Here are a set of statements. Some of them are true of you and so you will circle the yes. Some are not true of you and so you will circle the no. Answer every question even if some are hard to $\overline{d e}-$ cide, but do not circle both yes and no. Remember, circle the yes if the statement is generally like you, or circle the no if the statement is generally not like you. There are no right or wrong answers. Only you can tell us how you feel about yourself, so we hope you will mark the way you really feel inside (Piers and Harris 1969).

Children were also asked to respect the privacy of others, and advised that help with unfamiliar words would be given as needed. They were told that the results would be confidential. The majority of the class members read and responded individually, requiring little help. For children unable to read the items, the test was read aioud.

\section{TREATMENT}

The children in the experimental group werelulac asked to do individual, original writing of some form each day for the duration of the experiment. Experiences, observations, stories, pictures, or special events provided the means by which will lese

the writing was motivated. J On Arbor Day, for example, a short walk was taken beyond the borders of the play area to the edge of the schoolground where a number of young trees had been planted earlier in the year. Children made various observations. The trees were known to be Douglas Fir, the Oregon 
State Tree. Many children considered them Christmas trees. A number of the trees were not in a vertical position but were inclined or leaning. Someone remembered the windstorm of the previous week. Others shared their knowledge concerning damage done by the storm. Some children found flowers which were growing in the grassy area. A girl discovered a red ladybug on a branch of one tree. The needle-shaped leaves of the conifer were studied. When the recess bell rang, the children were dismissed. However, a number of the boys and girls remained in the grassy area near the trees, where they continued to exchange ideas. well

Group discussion oceding writing is believed to be an important part of the writing activity. The exchange of ideas appears to be stimulating, even for those who do not contribute. In the classroom, there was an opportunity to share orally individual findings. A variety of observations had been made. Douglas Fir which had been growing for perhaps two hundred years were visible from the window. The contrast in size was impressive.

It appears that thinking and talking together gives each individual time to decide on the particular element in the experience which will provide the basis for his writing. Each individual is free to choose the form his writing will take. Paper provided allows space for drawing a picture. It is believed that many children write more readily after they have expressed their thoughts or observations pictorially. For children who need help with spelling, words and phrases 
are written on paper. Children unable to write independently dictate their story and copy it under the picture they have made.

During the eight-week experimental period, writing was done on a variety of topics. On some days, the writing followed experimentation with science equipment such as magnets. Several days were required when a high school cadet teacher, under the direction and guidance of the classroom teacher, helped the class write Haiku poetry:

A brief outline of the Haiku writing activity, as well as selected writing topics and samples of the children's writing, will be found in the Appendix. 2 The control group continued to follow the standard curriculum during the experimental period. The experiences of this group were varied, and included a study trip to the Oregon Museum of Science and Industry. They worked as usual in basal readers and spelling workbooks. They had much practice with the principles and rules of language and grammar. The control group wrote approximately four times, or every other week, during the eight weeks. Their writing experiences 20

Included: writing to complete a story beginning, writing a story about a picture, writing a group poem, and writing letters to pen pals in another school. 
CHAPTER IV

\section{ANALYSIS OF DATA}

There were two purposes to be attained by this study: The first, to devise and experiment with techniques designed to promote individual writing among children in the third grade, was evaluated on the basis of informal, subjective observation. The second, to test the hypothesis that positive feelings about self can be increased measurably among children as a result of emphasizing original writing in the curriculum, was investigated by means of a self concept scale administered at the beginning and again at the conclusion of the eight-week experimental period.

\section{RESULTS}

On the basis of informal, subjective observation, the results of emphasizing writing in the curriculum included the following: (I) increased ability to work independently; (2) greater confidence in approaching and completing work which involved writing; (3) increased ability for oral and written expression; and (4) apparent satisfaction with the writing product.

The primary goal of the writing program was to promote feelings of success and satisfaction. It is believed that this goal was attained. Children were observed reading to 
each other stories just completed. Books on the reading shelf which contained typewritten copies of the children's stories were read and reread. It appeared that children were interested in others' stories as well as their own. On the basis of composition length and variety of ideas expressed, increased ability for written expression was observed. No attempt was made to measure growth in spelling. It was observed, however, that spelling was reasonably correct, since the children were encouraged to ask to have words spelled. At the conclusion of the experimental period, the self concept scores of each individual were compared. To demonstrate a significant difference, a change in individual raw scores of ten or more points was required. The raw scores of four subjects in the experimental group and two subjects in the control group increased by ten or more points, as indicated on Table I. Also shown on Table $I$ is the following information for each subject: the average reading score attained on the Metropolitan Achievement Test administered during the experimental period; the raw score achieved on the Piers-Harris Children's Self Concept Scale for pretest and posttest; the sums of the raw scores; and the mean for each sum.

The significance of the differences between the means was tested according to the analysis of variance and the resulting $\underline{t}$ test. Comparisons were made between the pretest and posttest means for each group; between pretest means for the experimental group and the control group; and between 
TABLE I

SELF CONCEPT REPORT SCORES

EXPERIMENTAL GROUP

Subject Read. Pre- Post-

14.6

$\frac{1}{2}$

$3-6.0$

$\begin{array}{ll}4 & 1.6 \\ & 2.5\end{array}$

$5 \quad 5.2$

$6 \quad 2.9$

$7 \quad 4.9$

$8 \quad 3.9$

$9 \quad 7.6$

$10 \quad 4.5$

II 2.9

$12 \quad 2.1$

134.3

142.1

$15 \quad 2.7$

$16 \quad 3.7$

$17 \quad 2.9$

$18 \quad 5.0$

194.6

$20 \quad 1.0$

$21 \quad 5.0$

$22 \quad 3.1$

$23 \quad 2.6$

$24 \quad 2.4$

$25 \quad 1.1$

sums

Means
$3939 *$

$76 \quad 74$

$50 \quad 51$

3840

$4154^{*}$

$5972^{*}$

$36 \quad 32$

$62 \quad 59$

5561

5149

5156

$52 \quad 53$

$61 \quad 62$

$66 \quad 68$

$43 \quad 51$

$34 \quad 36$

$46 \quad 45$

$46 \quad 53$

5560

$67 \quad 68$

$72 \quad 72$

5358

$4959 *$

$74 \quad 70$

$\begin{array}{ll}67 & 72 \\ 52 & 49\end{array}$

$1385 \quad 1463$

53.256 .2

CONTROL GROUP

Subject Read. Pre- Post-

$\begin{array}{llll}1 & 2.5 & 61 & 67\end{array}$

$2.2 .1 \quad 49 \quad 61^{*}$

$3 \quad 4.2 \quad 48 \quad 54$

$\begin{array}{llll}4 & 2.7 & 39 & 35\end{array}$

$\begin{array}{llll}5 & 3.2 & 74 & 75\end{array}$

$\begin{array}{llll}6 & 3.4 & 62 & 63\end{array}$

$\begin{array}{llll}7 & 3.4 & 42 & 43\end{array}$

$\begin{array}{llll}8 & 8.0 & 63 & 72\end{array}$

$\begin{array}{llll}9 & 2.3 & 68 & 74\end{array}$

$\begin{array}{llll}10 & 2.4 & 49 & 58\end{array}$

$\begin{array}{llll}11 & 3.9 & 64 & 57\end{array}$

$12.2 .2 \quad 38 \quad 31$

$13 \quad 4.4 \quad 54 \quad 64^{*}$

$14 \quad 2.0 \quad 67 \quad 73$

$\begin{array}{llll}15 & 4.2 & 58 & 64\end{array}$

$\begin{array}{llll}16 & 4.2 & 49 & 57\end{array}$

$\begin{array}{llll}17 & 3.8 & 27 & 36\end{array}$

$\begin{array}{llll}18 & 2.4 & 63 & 66\end{array}$

$\begin{array}{llll}19 & 3.8 & 58 & 57\end{array}$

$20 \quad 5.0 \quad 54 \quad 59$

$\begin{array}{llll}21 & 1.9 & 63 & 68\end{array}$

$\begin{array}{llll}22 & 2.9 & 60 & 56\end{array}$

$\begin{array}{llll}23 & 2.8 & 51 & 44\end{array}$

$\begin{array}{llll}24 & 4.6 & 75 & 75\end{array}$

$\begin{array}{llll}25 & 2.7 & 51 & 49\end{array}$

$\begin{array}{llll}26 & 3.5 & 56 & 62\end{array}$

Sums

14491552

Means

$55.5 \quad 58.4$

*Individual gain of 10 or more points is significant. 
posttest means for the experimental group and the control group. The result of these comparisons is available here. For significance at the .05 level, 4.03 is required (Ferguson 1966). A more detailed report of the analysis is presented in Table III.

\section{TABLE II}

Comparison Made

Experimental group pretest to posttest . . . 1.58 Control group pretest to posttest

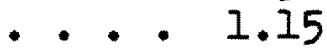
Experimental group pretest to control group pretest ... 1.08 Experimental group posttest to control group posttest ... . .89

*Required for significance at the .05 level, 4.03

There was no significant difference between the experimental group scores from pretest to posttest. There was no significant difference between the control group scores from pretest to posttest. A comparison of the experimental group pretest scores to the control group pretest scores indicated no significant difference. A comparison of the experimental group posttest scores to the control group posttest scores indicated no significant difference. 
TABLE III

COMPARISON OF EXPERIMENTAL AND

CONTROL GROUPS: PRETEST

$\begin{array}{crcc}\text { Source of } & \text { Sums of } & \text { Degrees } & \text { Variance } \\ \text { Variation } & \text { Squares } & \text { Freedom } & \text { Estimate } \\ \text { Between } & 78.6 & 1 & 78.6 \\ \text { Within } & 6398.2 & 50 & 127.96 \\ \text { Total } & 6476.8 & 51 & \text { F }=1.08\end{array}$

COMPARISON OF EXPERIMENTAL AND

CONTROL GROUPS: POSTTEST

$\begin{array}{cccr}\begin{array}{c}\text { Source of. } \\ \text { Variation }\end{array} & \begin{array}{c}\text { Sums of } \\ \text { Squares }\end{array} & \begin{array}{c}\text { Degrees } \\ \text { Freedom }\end{array} & \begin{array}{r}\text { Variance } \\ \text { Estimate }\end{array} \\ \text { Between } & 66.94 & 1 & 66.94 \\ \text { Within } & 7135.59 & 50 & 142.71 \\ \text { Total } & 7202.53 & 51 & \mathrm{~F}=.89 *\end{array}$

\section{COMPARISON OF EXPERIMENTAL GROUP}

PRETEST TO POSTTEST

Source of
Variation
Between
Within
Total

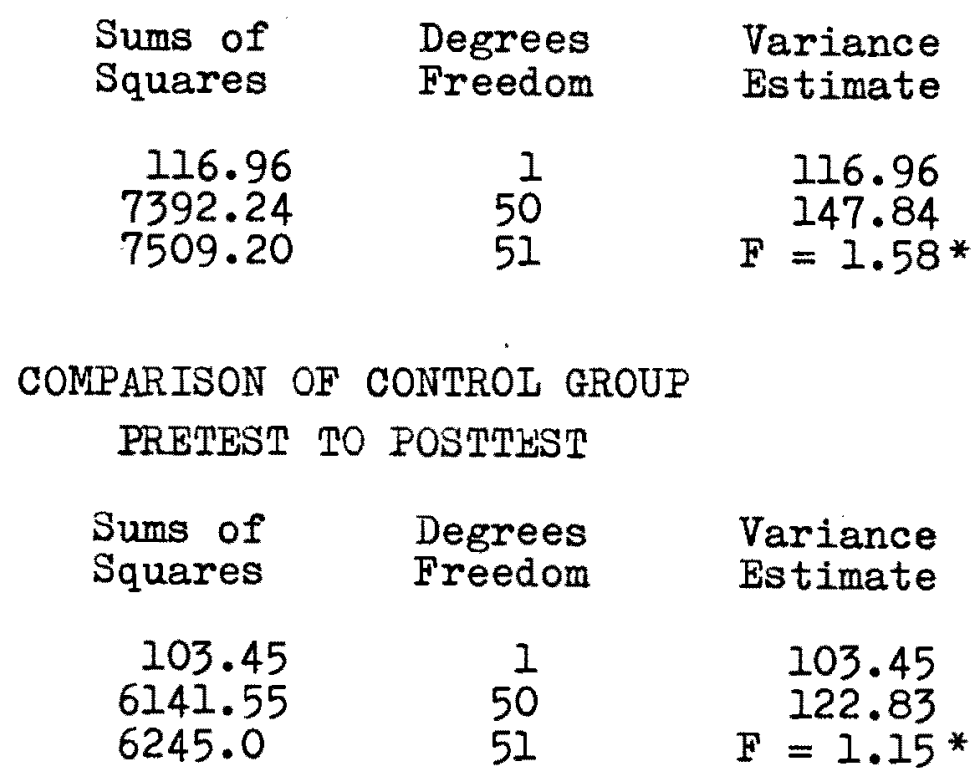

50

$51 \quad F=1.58$ *

50

$51 \quad F=1.15$ *

* Required for significance at the .05 level, 4.03 


\section{FINDINGS}

The findings of this study indicate no significant differences to the self concepts of children in the experimental group as compared to the children in the control group. On the basis of this study, therefore, the hypothesis that positive feelings about self can be increased measurably among children as a result of emphasizing original writing in the curriculum cannot be accepted. The study was limited in number of subjects and by the brief, eight-week experimental period. If the study had occurred earlier in the school term, and if it had been of greater duration, the possibility exists that more favorable results would have been obtained.

The control group attained somewhat higher scores than the experimental group on the pretest and again on the posttest. However, it nay be observed that the change or difference in total scores from the initial to the final test was comparable for both groups (Table I). Greater variation from pretest to posttest was exhibited by the experimental group than by the control group. Variation between the two groups decreased in final self concept scores at the conclusion of the experimental period.

The raw scores of four subjects in the experimental group and two subjects in the control group increased by ten or more points. This change in individual scores is considered significant. Due to the evident stability of test results, it appears scores were reasonably valid. Although it 
has been suggested that attitudes toward the self may be affected by the immediate situation, particularly in the case of jounger children, it is believed that by the age of eight or wine, children's self attitudes have attained a degree of stability. It is recognized that differences could be due to environmental factors other than the individual writing activity or experimental treatment. In an attempt to determine the factors responsible for significant gains being made, a study has been made of each of the four individuals whose scores increased by ten or more points.

\section{SUBJECT CASE STUDIES}

Self-esteem is believed important to the individual's social, emotional, and academic development. A study of the subjects whose scores changed significantly may afford insight into possible causes for increased self-esteem.

Subject Number One

This subject moved ten points in the direction of more positive self concept, as revealed on her self report; however, her score remained in the low category. It appears that the way in which she saw herself was not the way in which she might be evaluated by another person. She had high creative and academic ability, was interested in a wide variety of subjects, and always appeared to have friends. Many requests for privileges were granted. She was allowed to feed and care for the rabbits in the courtyard, to feed the wild birds, and, in 
the spring, to keep the bird baths cleaned and supplied with water. She enjoyed making things: a scarecrow, puppets, a series of pictures on rolled paper which resembled a motion picture when viewed through an opening in a box. She found and collected unusual items: the lid to a kettle, odd pieces of iron, rocks, broken bricks. After leaving these on the exhibit table for a time, she always retrieved them and carried them home.

A conference with her mother revealed that she was sometimes moody and unhappy at home. She had an older sister and a brother six or seven years younger than herself. Although there were things about school which she appeared to enjoy, her response to the statement, "I hate school" was "yes" on both self reports. Statements on the final self report to which she answered "no" were: I am a happy person. I am an important member of my family: I like my brother or sister. "Yes" answers were marked for the following statements: It is hard for me to make friends. I am often sad. I am shy. I cause trouble to my family. I pick on my brothers and sisters. I am unhappy. I am picked on at home.

A comparison of the initial and final reports revealed that answers changed from a negative to a positive response, and having "yes" answers, were: (1) I am smart. (2) I am good in my school work. (3) I can draw well. (4) I have nice hair. "No" was the response to: (5) I wish I were different. (6) My family is disappointed in me. (7) I am different from other people. (8) I would rather work alone than with a group. 
(9) I am dumb about most things. (10) I get into a lot of fights (the words "at home" were printed after this statement on the first report, when the response to this item was "yes").

The first three items, and items eight and nine, could indicate changes in attitude about things at school. Items six and ten are interpreted to suggest changed attitude about the home. The remaining items could refer either to home or to school. It appears that school was perceived somewhat more favorably than it had been perceived previously.

This subject's writing was individual in content and style, and it increased in originality and length. Late in the year she wrote and illustrated a story of perhaps ten pages entitled, "The Bunny Who Wanted a Name." It appeared that her purpose in writing was to gain recognition rather than to satisfy a need for self-expression. However, she seemed to find satisfaction in the finished product.

Subject Number Five

This subject, a girl, made a significant gain of thirteen points, moving from the low to the average category. She was the first child in a family of three, and had a younger sister and a baby brother. Emotional tension appeared to exist between this girl and her mother. Some of the statements to which she responded in a negative way seem to indicate this. The response to the following items was "yes": I am often sad. It is usually my fault when some- 
thing goes wrong. I usually want my. own way. I behave badly at home. I pick on my brothers and sisters. I often get into trouble. To the item, "I am an important member of my family", the answer marked was "no."

The fact that this subject made exceptional progress in original writing may or may not have been a factor in her gain in self-esteem. She enjoyed reading, and was intelligent, questioning, and creative. Her progress in writing would confirm findings which indicate a positive correlation between reading ability and proficiency in written expression. On a number of occasions she wrote several pages. The most lengthy composition was a booklet which she carefully illustrated entitled, "The Lost Easter Egg." The story concerned a family (her own) one member of which was named "Egg":

They lived up on a high hill. All of them were happy and gay--all of them, that is, except Egg. He was the littlest of them all. All of them pushed him around everywhere. So he ran away. He came to a forest and wandered around. Pretty soon he got lost and cried. He found a little house (which isn't in this picture but in the next). He lived in it...

In an involved story the lost Egg met a fairy, was advised to follow the stream, found a wishing pond, was told to follow the forest, and also followed the flowers for many days before he found his way home again, after which "they were all happy and gay."

It might be speculated that this introspective individual was searching for a home which was "happy and gay." Parent-child interaction is believed to influence the child's feelings of self-respect, since through being accepted and 
loved he comes to accept himself.

Subject Number Six

This subject, a girl, was an average student at the beginning of the school year. She enjoyed receiving attention, and achieved this goal by organizing or taking part in creative dramatic play. D During the latter part of the year, however, she appeared to perceive herself as having greater ability for academic achievement than she may have previously realized. She seriously tried to excel in her school work. She appeared to enjoy the satisfaction derived from achievement and success. Her progress was observed by her mother, who offered praise and encouragement. Recognition and success appeared to provide the incentive for greater effort. Observable progress was made in original writing. The illustrations were carefully made, and the writing was done in cursive. Being a creative and imaginative person, she had never lacked interesting ideas.

Items which were responded to negatively on the first self report and positively on the final report were identified. Items to which the response was "yes", were: I am smart. I have good ideas. I have pretty eyes. I can give a good report in front of the class. My friends like my ideas. I am obedient at home. I have a pleasant face. I am popular with girls. I am a good reader. I am an important member of my class (the answer was modified by the added words, "I am in the middle"). Items to which the response was "no", were: 
I am often sad. I give up easily. I cry easily.

Consideration of this subject and her reported growth in self-esteem appears to indicate that, although the school is an important factor in shaping self concept, the influence of the home and the attitude of the parents predominate in the organization of the child's feelings about self. Parental approval and acceptance appear more fundamental and lasting in building self-esteem than the influence from any other source. In this case, success in school may have provided the means to receiving praise and appreciation from those who mattered most.

\section{Subject Number Twenty-three}

This subject, a boy whose score changed from forty-nine to a more positive fifty-nine, joined the class in October. Although his mental ability was high, he had repeated the second grade and was experiencing difficulty with reading. He viewed himself as a nonreader, and often hurt other children. An extensive vocabulary and skill in oral expression were this boy's assets. He usually participated in any oral activity and shared in detail experiences and observations. He spoke well and had no difficulty in keeping the attention of the group. His first success appeared to be felt as a result of doing original writing or composition. Growth was observed in number of words written, length of sentences, ideas expressed, and apparent satisfaction. Reading materials were adapted to the needs of each individual. Since 
there was no need to compete, this boy began to gain confidence in his ability to learn to read. A vision difficulty was found and corrected. This appeared to accelerate his progress.

A conference with his parents revealed their concern. They considered themselves responsible for his difficulty with reading. They stated that he had begun to talk at an early age, and had exhibited an ability to remember much information. They had believed that he was ready to enter school at the age of five. When he discovered that he could not compete, he began to dislike school. Failure to succeed in

- school, and repeating a grade, induced feelings of discouragement.

As this child began to read adequately, and to improve in other learning areas, his parents expressed their pleasure and satisfaction. They let him know that they were pleased with his progress, and as a result, he made a greater effort to achieve. His attitude about himself began to change. It appears that a primary influence in the development of selfesteem is perceived parental approval.

Statements in the self report to which this boy responded negatively on the first test and positively on the final test were: I am often sad. I am good in my school work. I am an important member of my family. My parents expect too much of me. I am unhappy. I lose my temper easily. I do many bad things. 
This boy's first success in learning appeared in the area of original writing. He discovered that he could put into words on paper for others to read some of the many ideas which he had expressed orally. Positive feelings about self were reinforced by parental approval, encouragement, and understanding. 


\section{CHAPTER V}

\section{INTERPRETATIONS AND IMPLICATIONS}

It must be remembered that any test score, and partiularly a score derived from a personality inventory or self concept scale, is no more than an indication of ability or beliefs, and must be interpreted with restraint. The difference between true concept of self and revealed self concept has been mentioned by a number of writers. It has been pointed out also that children's self reports tend to correspond only slightly to the results of teacher's and peer's ratings.

Initially it was believed by the investigator that having each child read and respond to the self report scale individually would result in more accurate self ratings. It is now considered probable that for children at this level it would be advisable to have the items read aloud by the examiner. It was believed also that more accurate reports would be obtained if the test were administered by the classroom teacher in the usual classroom environment. The possibility exists that, under different circumstances, the results obtained. would have been different.

An increase in variance has been interpreted to mean reinforcement of present behavior and attitudes, resulting in greater range or distribution of scores from high to low. 
A decrease in variance indicates greater uniformity, or a tendency to approach the mean. In the present study, it appears that performance was fairly consistent from pretest to posttest. A decrease in variance between the two groups was observed on the final test. It has been suggested that remembering test items and tending to respond in the same way may affect posttest results.

Informal observation provided the only means to determining the development of individual attitudes and abilities as each child wrote independently, expressing his ideas, observations, and experiences in his own way. There appeared to be increased feelings of confidence and personal satisfaction associated with the writing program, particularly among children who had experienced difficulty with reading. This may indicate that having one's ideas recorded for copying gives one a sense of achievement and is an effective approach to reading.

Consideration of four individuals whose scores increased by ten or more points appears to indicate that environmental factors responsible for the difference were more directly related to family and home than they were to school; however, success in academic achievement for two of the four is seen as an important reason for increased parental approval. This tends to agree with findings which indicate that a positive and significant correlation exists between perceived ability or achievement and the way in which individuals view or rate themselves. Also, it appears to emphasize the importance of 
parental attitudes to the child's developing self.

At the present time self theory is accepted to the extent that educators might wisely include as a primary goal the promotion of feelings of dignity and worth in each individual. There may be certain ideal teaching methods or school situations which would tend to promote positive feelings about self. Essential to such a proposal is the acceptance of each individual as a person having special and unique talents, abilities, and characteristics.

Conditions and experiences conducive to expression of self will promote individuality. Opportunity for verbal expression encourages thinking, self-understanding, and involvement with the learning process. Emphasizing individual oral and written expression is an important means by which these purposes may be attained.

Further investigation concerning self theory and the relationship of self concept to variables in the school environment is indicated. Replication of the present study is suggested. Significant and valid results could follow experimental treatment of two or three years duration involving a large number of subjects. The present study was limited by time and number of subjects. More accurate means of measuring self concept could be devised. Through extended study, the present hypothesis might be upheld.

It is believed that the results of a particular instructional program or learning situation are not always observable immediately upon the conclusion of that program. Effects may 
not be apparent until an interval of time has elapsed. Therefore, outcomes in terms of learning and attitudes are not easily established.

\section{SUMMARY}

The purposes of this study were: (1) to devise and experiment with techniques designed to promote individual writing or composition among children in the third grade and to evaluate the usefulness or productiveness of those techniques, and (2) to test the hypothesis that positive feelings about self can be increased measurably among children as a result of emphasizing original writing in the curriculum. Two heterogeneous third grade classes, each composed of twenty-six pupils, constituted the experimental and the control group. The instrument used to obtain self concept report scores initially and again at the conclusion of an eight-week experimental period was The Piers-Harris Children's Self Concept Scale (1969). The children in the experimental group were asked to write a composition every day. Group discussion preceding writing was an important part of the writing activity, as was drawing a picture prior to writing. Compositions were based upon individual or group experiences, observations, and reactions. Occasionally a story, picture, or special event motivated the writing. Children who experienced difficulty with writing and spelling were allowed to dictate their story and copy it under the picture they had drawn. The control group wrote an average of four 
times, or every other week, during the eight-week experimental period.

At the conclusion of the experimental time, the self concept report scores for individuals within the groups were compared. To demonstrate a significant change, a difference in individual raw scores of ten or more points is required. The raw scores of four subjects in the experimental group and two subjects in the control group increased by ten or more points. The significance of the differences between means was tested according to the analysis of variance. The findings of this study indicated no significant differences to the self concepts of children in the experimental group as compared to the self concepts of children in the control group. Over the period of time allowed for the study, no significant differences to the self concepts of children in the experimental group, and to the self concepts of children in the control group, were found. On the basis of this study, therefore, the hypothesis that positive feelings about self can be increased measurably among children as a result of emphasizing original writing in the curriculum cannot be accepted. 


\section{REFERENCES}

Applegate, Mauree. Helping Children Write. Evanston, Illinois: Row, Peterson and Company, 1961.

Arnstein, Flora J. Adventure into Poetry. Stanford, California: Stanford University Press, 1951.

Ashton-Warner, Sylvia. Teacher. New York: Simon and Schuster, 1963.

Baldwin, Michael. Poetry Without Tears. Iondon: Routledge \& Kegan Paul, 1959.

Barnes, Donald I. "An Experimental Study in Written Composition." Elementary English, XII (January, 1964), 5I-2.

Biesbrock, Edieann F., and Ramon I. Veal. A Study Comparing Global Quality and Syntactic Maturity in the writing Composition of second and Third Grade students. Washington, D. C.: United States Department of Health, Education, and Welfare, 1969.

Bledsoe, Joseph C., and Karl C. Garrison. The Self Concepts of Elementary School Children. Athens: University of Georgia, 1962.

Brandt, Richard M., and Hugh V. Perkins. Research Evaluating a Child Study Program. Yellow Springs, Ohio: The Antioch Press, 1956.

Brookover, Wilbur B.; Paterson, Ann; and Thomas, Shailer. Self-Concept of Ability and School Achievement. East Lancing, Michigan: Michigan State University, 1962.

Buros, Oscar Krisen, ed. The Sixth Mental Measurements Yearbook. Highland Park, New Jersey: The Gryphon Press, 1965.

Burrows, Alvina Treut; Jackson, Doris C.; and.Saunders, Dorothy 0 . They All Want to Write. New York: Holt, Rinehart and Winston, 1964.

Burrows, Alvina T. What Research Says to the Teacher: Teaching Composition. Washington, D. C.: National Education Association, 1968. 
Carlson, Ruth K. Stimulating Children in Grades Four, Five, and Six to Write Original Stories. Unpublished PhD. Dissertation. Berkeley: University of California, 1960.

Carrithers, Iura M. Communication in the Elementary School. Oshkosh, Wisconsin: Wisconsin Council of Teachers of English, Inc., 1964.

Certner, Simon. Tested Topics and Techniques for Improving Writing. New York: Teachers Practical Press, Inc., 1964.

Chukovsky, Kornei. From Two to Five. Berkeley: University of California Press, 1963.

Clegg, A. B., ed. The Excitement of Writing. London: Chatto \& Windus, $196 \overline{6 .}$

Cole, Natalie Robinson. Children's Arts from Deep Down Inside. New York: The John Day Company, 1966.

Combs, Arthur W. Child Perceptions. Gainesville: University of Florida, 1963.

Combs, Arthur W., and Daniel W. Soper. The Relationship of Child Perceptions to Achievement and Behavior in Early Years. Cooperative Research Project No. 814. United States Department of Health, Education, and Welfare. Gainesvilie: University of Florida, 1963.

Cowe, Eileen. "The Beginnings of Writing as an Extension of Thinking and Talking." Elementary English, XIIX (January, $1972 h, 68-9$.

Cutforth, J. A. English in the Primary School. Oxford: A. T. Broome \& Son, 1959.

Davidson, Helen H., and Judith W. Greenberg. School Achievers from a Deprived Background. New York: The City Coliege of the City University of New York, 1967.

Dawson, Mildred A. Guiding Ianguage Learning. New York: World Book Company, 1957.

Dawson, Mildred A. and Frieda Hayes Dingee. Children Learn the Language Arts. Minneapolis, Minnesota: Burgess Fublishing Company, 1959.

Draper, Arthur G. "Teach the Process of Writing." English Journal IXVIII (February, 1969), 245-8. 
Evertts, Eldonna I., ed. Explorations in Children's Writings. Champaign, Illinois: National Council of Teachers of English, 1970.

Ferguson, George A. Statistical Analysis in Psychology and Education. New York: McGraw-Hill Book Company: 1966.

Fitts, William H. Manual, Tennessee Self Concept Scale. Nashville, Tennessee: Counselor Recordings and Tests, 1965.

Lrale, Raymond F. Developmental Behavior: A Humanistic Approach. London: The Macmillan Company, CollierMacmillan Iimited, 1969.

Godshalk, Fred I.; Swineford, Frances; and Coffman, William E. The Mieasurement of Writing Ability. New York: College Entrance Examination Board, 1966. To fe

Golub, Lester S. "Stimulating and Receiving Children's Writing: Implications for an Elementary Writing CurricuIum." Elementary English, XIVIII (January, 1971), 33-49.

Greene, Harry A. and Walter T. Petty. Developing Language Skills in the Elementary Schools. Boston: Allyn and Bacon, 1963.

Holbrook, David. Children's Writing. New York: Cambridge University Press, 1967.

$\checkmark$ Jersild, Arthur T. Child Psychology. New York: PrenticeHall, Inc., 1954.197

Kelly, Earl C. "The Fully Functioning Self." Perceiving, Behaving, Becoming: A New Focus for Education. Edited by Arthur W. Combs. Washington, D. C.: Association for Supervision and Curriculum Development, 1962.

Kuse, Hildegard R., and Betty Allar. "I Write More Better With a Partner." Elementary English, XIVIII (December, 1971), 984-8.

IaBrant, Iou. English in Common Learnings. Chicago: National Council of Teachers of English, 1951.

IaBrant, Lou. "Psychological Basis for Creative Writing." English Journal, XXV (April, 1936), 292-301.

Lane, S. M., and M. Kerp. An Approach to Creative Writing in the Primary School. Iondon: Blackie, 1967. 
Iangdon, Margaret. Let the Children Write. London: Longmans, Green and Co. Ltd., 1969.

Ieuba, Clarence. Personality, Interpersonal Relations, SelfUnderstanding. Columbus, Ohio: Charles E. Merrill Books, Inc., I962.

$V$ Levy, Leon H. Conceptions of Personality, Theories and Research. New York: Random House, Inc., 1970.

$\checkmark$ Iindeman, Richard H. Educational Measurement. Glenview, Ilinois: Scott, Foresman and Company, 1967.1983

Ioban, Walter. The Language of Elementary Children. Champaign, Illinois: National Council of Teachers of English, 1963.

Martin, Marvin. "Children Can Become Better Writers." Elementary English, XII (January, 1964), 53-5.

Moffett, James. A Student-Centered Language Arts Curriculum. Boston: Houghton Vifflin Company, 1968.

Murphy, Gardner. Personality: A Biosocial Approach to Origins and Structure. New York: Harper \& Brothers Publishers, 1947.

Nesper, Osanna. A Teacher's Experience With Comoosition. Evanston, Illinois: Northwestern University, 1965.

Omwake, Katharine T. "The Relation Between Acceptance of Self and Acceptance of Others Shown by Three Personality Inventories." Journal of Consulting Psychology, XVIII (December, 1954), 443-6.

Petty, Walter T., and Mary E. Bowen. Slithery Snakes and Other Aids to Children's Writing. New York: Meredith Publishing Company, 1967.

Piers, Ellen V. Manual for The Piers-Harris Children's Self Concept Scale, (The Way I Feel About Wyself). Nashville, Tennessee: Counselor Recordings and Tests, 1969.

Piers, Ellen V., and Dale B. Harris. The Piers-Harris Children's Self Concept Scale (The Way I Feel About liyself). Nashville, Tennessee: Counselor Recordings and Tests, 1969.

Purkey, William W. Self Concept and School Achievement. Englewood Cliffs, New Jersey: Prentice-Hall, Inc., 1970. 
Raimy, Victor. The Self Concept as a Factor in Counseling and Personality Organization. Columbus, Ohio: Ohio State University Libraries Office of Educational Services, 1971.

Russell, David H. "What Does Fesearch Say About SeliEvaluation." Journal of Educational Research, XIVI (April, 1953), 561-73.

Shackleford, Ruby P. "Let's Write Haiku." Elementary English, XIIX (March, 1972), 429-30.

Shapiro, Phyllis P. and Bernard J. Shapiro. "Two Methods of Teaching Poetry Writing in the Fourth Grade." Elementary English, XLVIII (February, 1971), 225-8.

Shay, D'Arcy C. "Creativity in the Classroom--Haiku." Elementary English, XLVIII (December, 1971), 1000.

Smith, Ethel Eudora. Procedures for Encouraging Creative Writing in the Elementary School. Doctor's thesis. Evanston, Illinois: Northwestern University, 1944.

Smith, Lewis, and Marlyn Willardson. "Communication Skills Through Authorship." Elementary English, XIVIII (February, 1971), 190-2.

$\checkmark$ Snygg, Donald, and Arthur W. Combs. Individual Behavior. New York: Harper \& Brothers Publishers, 1949.

Staudacher, Carol. Creative Writing in the Classroom. Palo Alto, California: Fearon Fublishers, 1968.

'Strickland, Ruth G. "Evaluating Children's Composition." Children's Writing, Research in Composition and Related Skills. Champaign, Illinois: National Council of Teachers of English, 1960-61.

Travers, Robert M. W. Educational Measurement. New York: The Macmilian Company, 1955.

Travers, Robert M. W. An Introduction to Educational Research. London: Collier-Viacmillan Limited, 1969.

Walter, Nina Willis. Let Them Writc Poetry. New York: Holt, Rinehart and Winston, 1962.

$\checkmark$ Wylie, Ruth.C. The Self Concept. Iincoln, Nebraska: University of Nebraska Press, 1961. 194 


\section{APPENDIX}

\section{ORIGINAI WR ITING}

The plan for original writing, developed over a period of three years, was intended to encourage learning among children who had experienced difficulty with reading. A primary purpose of the plan was to promote oral and written expression. Through listening and thinking, children may find that they have ideas which can be shared orally. Ideas which have been expressed orally can also be written.

Various experiences may be used to provide a reason for thinking and speaking. Questions encourage individual contributions. A variety of themes related to each subject may be discovered. Each individual chooses the theme or idea for his writing. A successful beginning can be made by drawing a picture to illustrate the idea selected.

\section{SELECTED TOPICS}

A short walk in September provided ideas for drawing and writing. This one was entitled "September Journey":

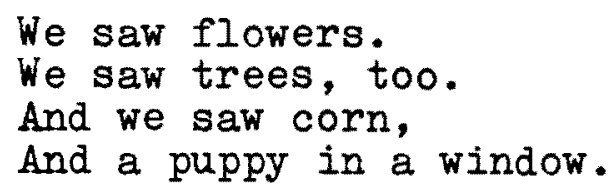

A beginning had been made with four brief sentences. Later in the year, the same child wrote an imaginative story 
of several pages about a lady who had "six boys and six girls and two cats and six dogs and five rabbits and fifty sheep and five cattle and I do not know how many lambs, she had so many animals; ..."

Each class had lessons on swimming at the new swimming pool. After talking about the experience, stories were produced:

$$
\begin{aligned}
& \text { This is our swimming teacher show- } \\
& \text { ing us how to float on our backs. I } \\
& \text { could do it! I could float on my stom- } \\
& \text { ach, too. }
\end{aligned}
$$

After reading the story, "All the Henrys" by Leonora Grunes (Merry-Go-Round, Charles E. Merrill Books, Inc., 1960) the class wrote to answer the question, "Who am I?":

I am my grandmother's helper. I am my father's son. I am my grandfather's tansy hoer. I am my brother's football player. I am my sister's brother.

Halloween witches with acorn heads were made ("Acorn Witch" by Anna Lou Case, Instructor, IXXX [October, 1970],50). One response to questions and discussion was the story of "A Good Witch" :

My witch's name is Amy. She lives in an attic. If somebody has only a little bit of candy, she puts a lot of candy in the sack. Amy is a good witch.

Halloween provides a variety of writing ideas: costumes, parties, remembered experiences, or just make-believe. Halloween poetry does not have to rhyme: 
When the Orange Moon

Was shining through the night

I was walking

And tip-toeing.

I saw witches

Go across the moon.

I knock on the door-$\mathrm{BOO}$ !

A few days before Thanksgiving, the children dressed like pioneers and spent a day in a little one-room school. If the writing had been done there, it might have been more successful. By the next day, interest had faded:

Our class went to an old-time school. We had our lessons there. We had to bring our lunches. There was a bell there and a man to tell us all about it. Our pictures were taken and put in the newspaper.

A poem, "November", by Aileen Fisher, illustrated the use of personification and promoted November writing:

November is an old man Ell tattered and torn.

He has a jacket

It is torn as could be.

$\mathrm{He}$ is colder than a mouse

And colder than a cat, And colder than a dog.

Thinking and talking about things associated with various colors provided a reason for writing:

I like the color blue That brightens the sky. And the way that the river looks With that lovely color blue. And the paper that comes From the trees that grow In the forest in the weeds. I like the color blue.

By February some stories were longer and more detailed. This was the story of the "Iittle Iost Valentine": 
Once there was a little lost Valentine. He didn't know which way was home. One day he saw a house. He looked in the window and saw a boy getting his valentines ready for Valentine's Day. When the boy wasn't looking, the valentine jumped down with the other valentines! Then the boy came back. He chose the little lost valentine to give to one of the children in his class. And the valentine lived happily ever after.

March brought sunny days. To find plants for a winter garden, the class went for a walk:

On our winter garden journey we saw some trees and pretty flowers. And I saw some birds, rocks, pond, moss, and a Meadow Lark, our state bird. And Oregon Grape, our state flower.

March also brought spring poems:

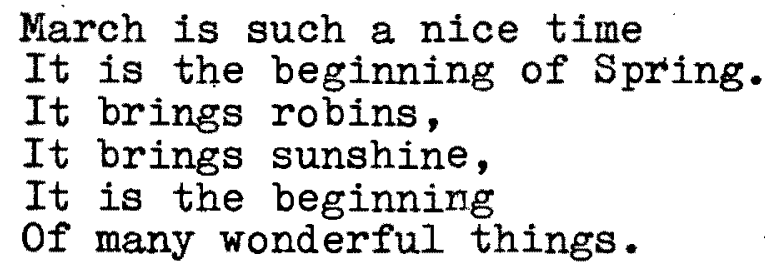

Rainy days followed the sunshine. To the question, "What might fall from the sky like rain?" there were many answers :

\author{
My Wish \\ I wish that presents \\ All wrapped up in pretty paper \\ Were faliing down \\ From the sky. \\ And I \\ Can open them \\ And find my best one. \\ It's Raining \\ It's raining \\ Boys and girls, \\ Go out and play. \\ It's raining everything ! \\ Clocks, dolls, candy \\ Keys, money, houses,
}


Tables, chairs,

Jack-in-the-boxes

And everything.

Dollars

Dollars, dollars

Millions of dollars.

Dollars, dollars

And dog collars.

They all come down

With a swish.

Oh, how I wish

It rained dollars.

A book, Animals on the Ceiling by Richard Armour

(McGraw Hill Book Company, 1966), was used to introduce the

idea of looking for shapes on the ceiling, in clouds, and

elsewhere:

\section{Cloud Picture}

In the sky I can see two Indians in a canoe paddling down a river. They are trying to find a good place to fish.

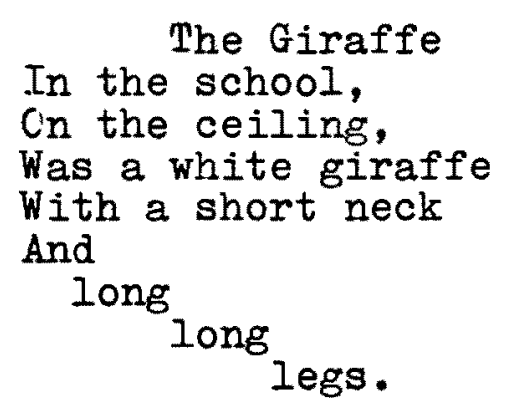

When a tree frog was brought to school, one child wrote:

Frogs feel weird. And they eat flies. And insects. And some frogs are different than other frogs.

Little frogs look cute. Little frogs have tails when they are babies.

The poem, "A Long Story" by Jessica Nelson North (The Organ Grinders' Garden, Rand McNally \& Company, 1942), was read and followed by the question: What would you do, if 
you lived in a shoe? For some children, stories were becoming longer:

We lived in a shoe. We built a swimming pool and we had windows and a door. We had little beds in a shoe 100 feet wide and 50 feet high. We got along really fine and that's how we were living in 1962, until a storm came up. It was a snowstorm. We could not get any food because it was. so very snowy. It stopped finally. Then a forest sprang up in one second. We chopped down trees for wood for a year. Then a fire came up. We were running out of the house in a hurry when the trees caught fire. We found another shoe and lived happily ever after.

After a walk to the school courtyard to observe the family of white rabbits, there were stories and poems:

$$
\begin{aligned}
& \text { Bunny, Bunny } \\
& \text { You're so white. } \\
& \text { Bunny, Bunny } \\
& \text { You're so bright. } \\
& \text { A Bunny doesn't } \\
& \text { Make a sound, } \\
& \text { A Bunny just } \\
& \text { Hops around. }
\end{aligned}
$$

The poem, "Just Me" by Margaret Hillert (Farther Than Far, Follett Publishing Company, 1969), turned attention to each child's individual self:

\section{Just $\mathrm{Me}$}

I am special at home.

$$
\text { I am different inside. }
$$

I like to play games. I like poems.

I go outside at night. I like to see flowers.

Just $\mathrm{Me}$

What scares me the most?

Snakes and spiders.

I am scared of spiders

Because once we were playing

Hide and Seek; and I hid 
Up in the garage. And there

Was a black widow spider

Up there. I called for my dad

And he got me down. (I was six.)

Writing may follow experimentation with science mate-

rials:

We all got a magnet or two. I put one magnet under a paper and another one on the top and moved the bottom one. The top one moved. Then I got a pin and rubbed it against the magnet. Then I put the needle on another one and it stuck to it.

Our class did an experiment. It was about some magnets. This is mine: I took a jar and two magnets and I put one of the magnets in the jar and the other one in my hand and moved it around and the other one moved.

Everyone planted a peanut in a paper cup. Writing was done on the day the plants were taken home:

One of the peanut plants is 10 inches and the other plant 8 and a half inches. I planted the peanut plant on Feb. 23, 1972. And my peanut plant is the biggest plant in my room and the other plants are not growing. There are 29 leaves on the 8 and $a$ half inches plant and on the other plant 24 leaves.

After the class saw a puppet show, this description was written:

Tuesday, April 18, 1972

We were invited to a puppet show. It was called The Wizard of $\mathrm{Oz}$. They made the puppets with no help at all. They hand carved them themselves. And painted them, too. The names were Dorothy, Toto, Glenda, wicked Witch, Scarecrow, Tin Woodsman, Cowardly Lion, Wizard. All the characters were real cute. They had red curtains. And they 
also made the curtains, too. It was a man and his wife. Just think ! Hand made.

Imaginary animals were drawn and described:

This animal's name is Looper- $\mathrm{Ka}-$ Zoopie. He's green because he's sick. He's blue because he's cold. He's red because he's hot. He always breathes fire.. This animal can be caught only in a Looper Sooper net. The handle has to be two miles long. He lives only in pink skies.

The story, "Flying High", (Just Imagine!, Scott Foresman and Company, 1953), was read before writing about individual experiences with high places:

When I lived in California, we had a fort. It was about 20 feet high. My brother and I always liked to climb to the top of it. One day we were at the top of it. We had a cloth over a little window and my brother was coming down that way. When he came down he slipped on the cloth and fell. There was a flat ball at the bottom. My brother hit his head on the ball. When he got up he was so scared that he didn't want to move.

To introduce Haiku poetry, a book, The Moment of Wonder edited by Richard Lewis (Dial Press, 1964), was used. Much of the preface was read aloud. To encourage an awareness of nature, questions like the following were asked: Have you seen a leaf falling? a drop of dew on a flower? a tiny insect on a window pane? Have you watched a butterfly slowly moving its wings as it rested on a flower? Have you seen cherry blossoms drifting like snow to the ground? On the following day, after more reading and discussion, a Haiku 
poem was composed by the group. Words about nature were used to provide practice in syllabication. Examples of Japanese art were provided. The children were interested in writing the three-line, unrhymed poems:

Snail, Snail, why

Do you carry your house

On your back? My, my, my. 